\title{
Tectonic control in the geomorphologic development of the Wadi el-Mujib canyon (Jordan)
}

\author{
Ch. de Jaeger * and M. de Dapper \\ Department of Geography, Ghent University, Krijgslaan 281 (S8), B-9000 Gent, Belgium \\ *Fund for Scientific Research Flanders, Brussels, Belgium
}

Received: 2 October 2000 - Revised: 24 September 2001 - Accepted: 26 November 2001

\begin{abstract}
A large part of Central Jordan is drained by the Wadi el-Mujib basin. This river developed a deep canyon through the Moab plateau, the eastern shoulder of the Dead Sea Rift. Intense subsidence of the base level at the Dead Sea is the main cause for the high rate of Pliocene/Pleistocene fluvial incision along the lower reaches of the Mujib basin. During this phase of accelerated incision the wadis were submitted to the presence of a dense fault net in the canyon area. The directions of the thalwegs correspond well with the apparent directions of the faults, indicating that fluvial incision occurred preferentially along tectonic lines characterized by rock weakness and discontinuity. Major convex knickpoints along the longitudinal profiles are caused by normal fault movement or due to the delay in headward erosion with respect to the main or local base level. Minor knickpoints correspond usually to differences in rock resistance. Climatic changes seem to be the principal cause for several types of Pleistocene deposits in the canyon but tectonic influence often played an additional role. Flash floods drive the principal incision events that result in effective erosion in the present dry semi-arid climate.
\end{abstract}

\section{Introduction}

The Wadi el-Mujib basin drains a large part of Central Jordan. Its principal wadis form a deep canyon complex that developed through the Moab plateau, the eastern uplifted shoulder of the Dead Sea Rift. The drainage development of the Wadi el-Mujib basin since the Late Oligocene regression of the Tethys, has been submitted to the combined effects of different environmental changes: rift activity, neotectonic history and climate changes. Since the Neogene a wide peneplain developed on the exposed Late Cretaceous and $\mathrm{Pa}$ -

Correspondence to: Ch. de Jaeger

(Chantal.dejaeger@rug.ac.be) leogene marine sediments by subaerial erosion. From the Pliocene on intense normal faulting occurred along the Dead Sea Transform, resulting in a topographic height difference of 1000-1500 $\mathrm{m}$ between the subsided base level or the Dead Sea, and the uplifted eastern rift shoulder. In a time span of less than $6 \mathrm{Ma}$ several deep canyons developed trough this young plateau. Apart from the study of Wdowinski and Zilberman (1997) on the topography of the rift margins and of Steinitz and Bartov (1992) on the erosion rates calculated for the Wadi Zerqa Ma'in canyon, few regional geomorphologic research has been done on the Jordan side of the rift.

In the attempt to reconstruct the geomorphologic evolution of the Wadi el-Mujib canyon, field observations, absolute dating, remote sensing techniques and Geographic Information System (GIS) applications are the basic methods and tools used to unravel the individual control of each environmental factor. The role of other, inherent factors, such as the lithology and the pre-Neogene tectonic structures need to be taken into account too. This paper focuses on the most important control: the regional and local tectonic frame.

\section{Tectonic setting in the study area}

\subsection{The Dead Sea Transform}

Since the Miocene the northern part of the $6000 \mathrm{~km}$ long Great E African Rift was submitted to important changes: by the opening of a Late Cretaceous trough the Red Sea was formed. As a result the old Levantine geosuture developed into a major sinistral transform fault, called the Dead Sea Transform (DST) running S-N from the Gulf of Aqaba up to southern Turkey (Ginat et al., 1998; Freund et al., 1970; Garfunkel, 1970; Ben-Avraham and Ten Brink, 1989). Horizontal and vertical movements along this "en echelon" fault caused the development of the deep Dead Sea basin and the uplift of the Jordanian Plateau as the eastern shoulder along 
the system (Wdowinski and Zilberman, 1997). Earthquakes occur frequently along the DST but are usually of rather low magnitude $(\mathrm{M}<=3)$. Magnitudes $>5.5$ have a mean recurrence time of 1600 years with a large standard deviation of about 2800 years (Marco et al., 1996; Enzel et al., 2000), and known maximum magnitudes do not exceed a value 7-7.5.

The Miocene $60-65 \mathrm{~km}$ horizontal offset was followed by relative subsidence of several hundreds to a $1000 \mathrm{~m}$ (Erythrean subsidence phase), while during the Pliocene and particularly through the Pleistocene the second $40-45 \mathrm{~km}$ horizontal offset was associated with subsidence reaching at least $6000 \mathrm{~m}$ (2000 and $4000 \mathrm{~m}$ respectively) in the Levantine subsidence phase (Kashai and Croker, 1987; Horowitz, 1987), reaching a total of about $7000 \mathrm{~m}$. However, this figure would be an underestimation of the amount of subsidence along the Dead Sea part of the transform since gravimetric surveys indicate that the Dead Sea basin covers a sediment sequence reaching $10000 \mathrm{~m}$ (Ten Brink et al., 1993).

\subsection{The Mujib area before the Late Tertiary}

In order to analyze the Late Cenozoic development of the Wadi el-Mujib canyon a short review on the tectonic situation in the area during the Paleozoic and Mesozoic is put forward. Atallah (1981) states that the oldest rocks in the Mujib area show evidence of tectonic activity by the presence of faults restricted to the Paleozoic sediments and which are clearly distinguished from the diagenetic joint fractures (Bender, 1975). Powell and Khalil (1993) explain that the small-scale horsts and grabens $\mathrm{N}$ of the Mujib-Wala confluence (Al-Mamalih structures) developed in response to a NW-SE extensional tectonic regime during Upper Jurassic/earliest Cretaceous. The grabens are filled by PermoTriassic strata, which are completely missing in the Mujib. Even marine Jurassic sediments do not occur in the $\mathrm{Mu}$ jib area. As they do occur on the western side of the rift and directly to the $\mathrm{N}$ of the Mujib area (Wadi Zerqa area), the first tectonic activity along the eastern rift border fault should be pre-Jurassic (Bentor and Vroman, 1960). However, it is a wrong assumption to pretend a uniform rising of the Mujib area since the Lower Mesozoic: Abed (1985) explained that some strata of the Upper Cretaceous marine sediments are especially thick for the Mujib area due to phases of local subsidence. But he argues that even these phases of subsidence were interrupted in the Mujib area by uplifting expressed by a local erosion surface (conglomeratic facies) upon $20 \mathrm{~m}$ Lower Cenomanian marine sediments. Moreover, Abed and El-Hiyari (1986) described the Upper Cenomanian/Lower Turonian gypsum horizon as deposits of a coastal sabkha extending over W Central Jordan but dying to the N of the Mujib area. To summarize, it may be said that the $\mathrm{Mu}$ jib area was submitted to vertical tectonic movements most probably since the beginning of the Mesozoic and although phases of subsidence are recorded for the Upper Cretaceous, tectonic uplifting dominated. As a result, the Paleozoic sandstones are well exposed and form steep cliffs in front of the Mujib area along the rift, where the Mesozoic sediments are missing due to the important Pliocene/Pleistocene erosion. After the regional regression of the Tethys in the latest Eocene/Oligocene (Barjous and Mikbel, 1990) terrestrial erosion dominated on the Jordanian plateau. Apart from the Late Cenozoic basalt sheets and some Paleocene and Eocene sediments locally preserved in small grabens, Late Cretaceous rocks are exposed on the plateau in the Mujib area. For that reason most post-Cretaceous fault lines appear at the surface, except on places where they are covered by landslide material (along the canyon slopes) or by soil or regolith (on the plateau). They usually show topographic expression, whatever the type of movement.

\subsection{The nature of the fault net in the Mujib area}

Atallah (1986, 1992a,b) shows that DST-associated faults with a main direction of $\sim 85^{\circ}$ (WNW-ESE to W-E) anticlockwise from the rift are often dextral (some of them should certainly be reactivated faults of the Sinai Negev Shear Zone (SNSZ)), those with a main direction of $\sim 45^{\circ}$ (NW-SE) anticlockwise from the rift are usual normal, while those with a main direction of $\sim 18^{\circ}$ (NNW-SSE or NNESSW) tend to be sinistral. On the geological maps of the study area most faults show however a dominant normal displacement, whatever the direction may be may be (faults, in black on Fig. 1). These faults are generated both by the SSF and DST. The Shihan-Siwaqa Fault (SSF) system, in yellow on Fig. 1) and the Zerqa Ma' in Fault (ZMF) - in between which the Mujib canyon complex is situated - are two prominent E-W directed faults most probably genetically related to the Central SNSZ that resulted from the central Syrian Arc Stress Field (SAS). If the common hypothesis of the Late Cenozoic $\sim 107 \mathrm{~km}$ sinistral horizontal movement along the DST (Quennell, 1959) is accepted, both faults are the post-Oligocene offsets of major fault lines that occur in the southern Negev in Israel. Quennell (1958) considered the E-W ZMF as the eastward continuation of the Ramon fault (Steinitz and Bartov, 1992), so that the SSF may be the offset of the Arif-Batur Fault or the Paran Fault. Along the SSF system effects of both vertical and horizontal displacement occur. As the plateau basalts are not displaced, the SSF is estimated to be structurally inactive since $6 \mathrm{Ma}$ but it may have served as a conduit for the erupting magma (Steinitz and Bartov, 1992). Apart from a $\sim 8 \mathrm{~km}$ dextral strike-slip movement along the E-W segment, the northern block is downthrown with a vertical displacement of $120 \mathrm{~m}$ in the $\mathrm{W}, 200 \mathrm{~m}$ for $7 \mathrm{~km}$ E of Wadi Nukheila and $100 \mathrm{~m}$ in Siwaqa area and in between there is some downthrown to the $\mathrm{S}$ (Khalil, 1992). This normal movement is expressed by a long crest that runs E from the Wadi Nukheila (Fig. 1) as an isolated morphologic feature, far into the Oligocene-Eocene pediplain of Central Jordan. Apart from the SSF another principal tectonic belt, the NW-SE Karak - Wadi El-Fayha Fault (KFF) system (in purple on Fig. 1), appears to have played a major role in the drainage development of the Mujib canyon complex. The normal graben-faults in the SE of the Mujib canyon area seem to form a northern offshoot of the KFF system. 


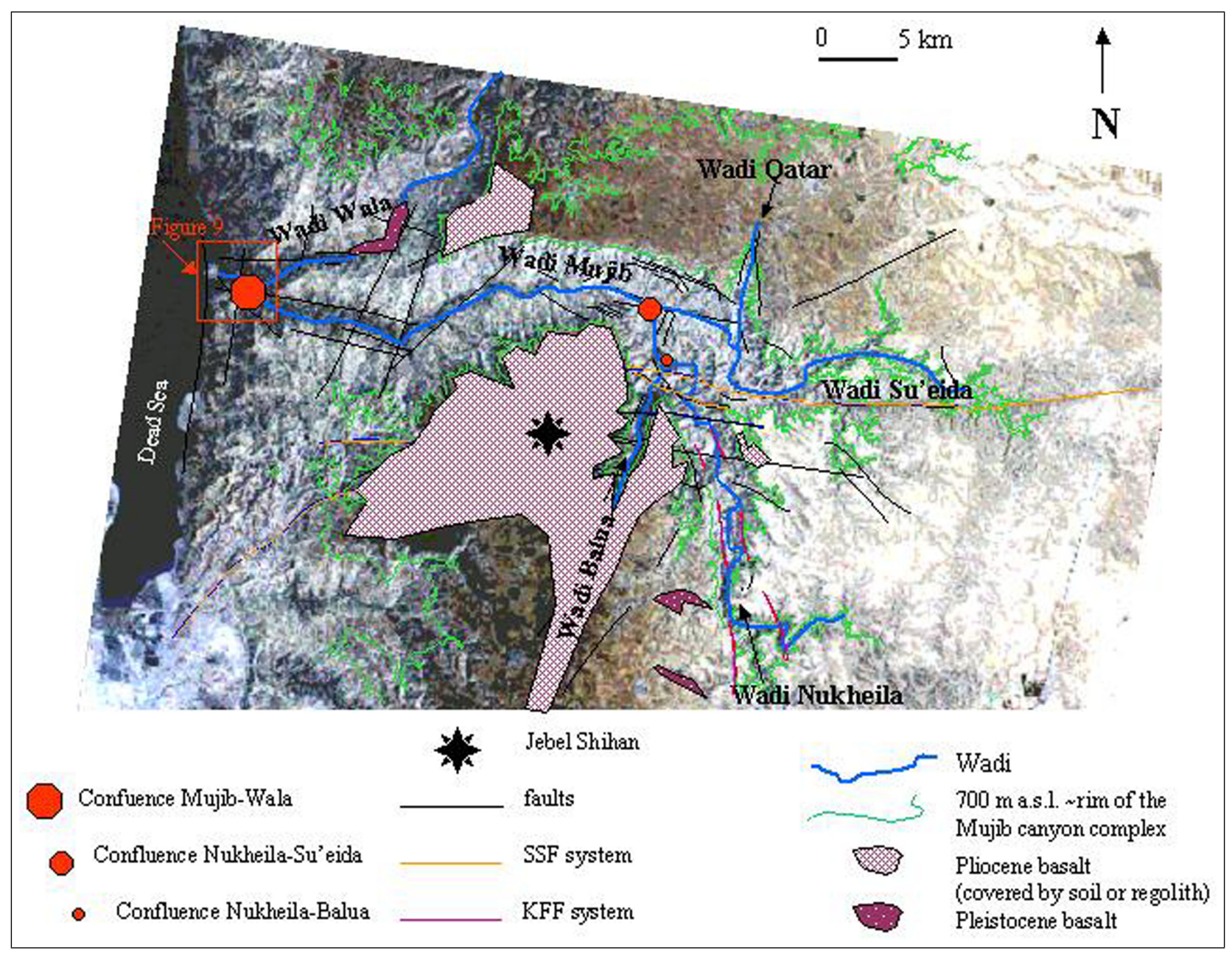

Fig. 1. Main wadis of the Wadi el-Mujib canyon complex and the tectonic setting. A rectified True Color Composite of a Landsat TM-scene (1997) is used as background.

\section{Model of the Mujib canyon development}

\subsection{Methodology}

In order to understand the tectonic control on the canyon's geomorphologic development, the fieldwork was focused on slope- and fluvial features in the canyon such as travertine terraces, alluvial terraces, screes, landslides and the Mujib fandelta. The integration of topographic, lithologic, tectonic and structural information into a GIS improved the interpretation of the observed features and allowed to calculate the wadi profiles. Several remote sensing documents, such as stereoscopic aerial photographs (scale: 1:30000), stereoscopic satellite imagery (Russian TK-350, U.S. Corona), a Landsat MSS-scene and a Landsat TM-scene are used as additional information sources and mapping tools. The geomorphologic evolution of this semi-arid study area is mainly ruled by the co-existence of a rapid base level subsidence since the Plio-Pleistocene and changes in temperature and precipitation during alternating climatic episodes in the Quaternary. It is a difficult task to separate the individual influ- ence of tectonics and climate on the drainage incision and the slope processes.

\subsection{Pre-Pliocene drainage}

The initial channel of the Mujib is supposed to have incised in the time-span between the regional regression of the Tethys (latest Late Oligocene) and the Late Miocene (before the second sinistral movement along the rift). The upper slopes in the lower Mujib canyon show evidence of a shallow-incised drainage network by transversal profiles of undeep channels $(<50 \mathrm{~m})$ at the top of the Upper Cretaceous sediments filled with basalt from the fissure eruptions at Jebel Shihan, about 6-8 Ma ago (Barbieri et al., 1980; Duffield et al., 1988; Steinitz and Bartov, 1992). The lower reach of the proto-Mujib channel, as well as the other main wadis draining the Central Jordanian plateau may have joined the great Miocene Hazeva fluvial system to discharge into the Mediterranean Sea via Nahal Besor (Zak and Freund, 1981) or the Beer Sheva canyon (Buchbinder and Zilberman, 1997). From the Upper Oligocene till the Middle Miocene the Dead Sea rift served as an intermediate basin 

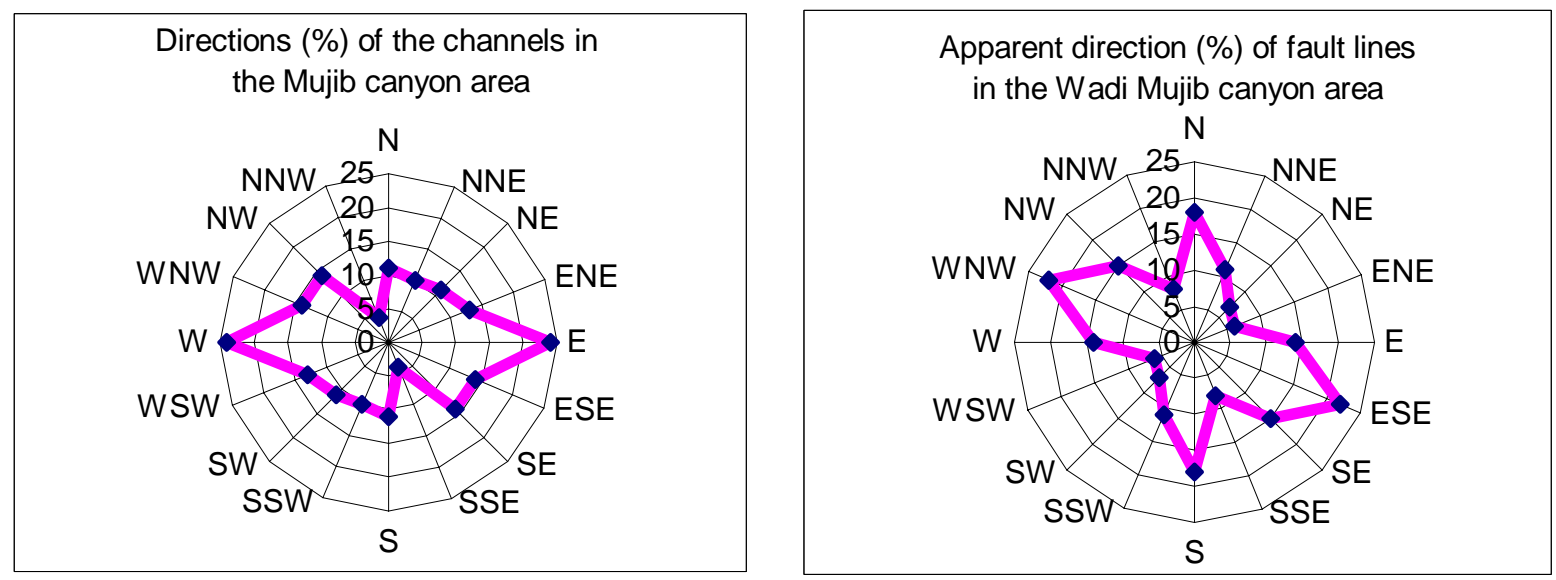

Fig. 2. Rose diagrams of channel respectively fault directions in the Mujib canyon area. On both diagrams NNW-SSE, NNE-SSW and NE-SW have low percentages. Many thalwegs seem to have exploited E-W to NW-SE and N-S directed faults in their drainage to the W.

of the Hazeva river system draining the southern and southwestern Levant (Horowitz, 1987). During the Late Miocene intense tectonic activity opened troughs both $\mathrm{S}$ of the present Dead Sea and in the central Jordan Valley, capturing previous drainage systems towards internal base levels where sediments could accumulate. The red fluvial Hazeva beds filled up the rift until rivers from the Jordanian plateau could cross it again in their flow to the Mediterranean Sea. Freund et al. (1968) suggest that the Rotem basin W of the rift was then part of the palaeochannel of the Mujib. Similar to the Hazeva system the Rotem basin testifies at least of two stages of Miocene incision. The last incision event is related to the upper members of the Hazeva Formation that include well-rounded layered allochthonous chert pebbles (Zilberman, 1993). They may be the erosion products of the upper Belqa Formation transported from Central Jordan.

\subsection{Pliocene/Pleistocene development}

During the past 5-6 million years the landscape has been submitted to rapid changes as intense normal faulting along the eastern rift border resulted in a relief difference of about $1200 \mathrm{~m}$ between the uplifted plateau and the subsiding Dead Sea basin. In a topographic study of the Dead Sea Rift, Wdowinski and Zilberman (1997) show that the Moab plateau is formed by $1000-1500 \mathrm{~m}$ structural uplift of the eastern rift shoulder while the western margin composes the hanging wall of a wide half-graben structure downflexed toward the rift axis in a wide asymmetrical monocline. Surface unloading due to $3-6 \mathrm{~km}$ horizontal extension perpendicular to the rift is probably the principal cause for the high tectonic uplift of the Moab plateau. In a model of seismic tomography of the Dead Sea region Rabinowitz and Mart (2000) show that magmatic upwelling occurs near the Ein Gedi Deep, characterized by crust thinning, anomalous velocities and possible magmatic diapirism. Thus, undeep magmatic upwelling by conduction could have enhanced the total amount of tectonic uplift along the eastern margin. By digital pro- cessing of an elevation model based on the contours derived from topographic maps (1:50000), the total volume of eroded sediments is estimated at about $113 \mathrm{~km}^{3}$ during the development of the Mujib canyon complex (Wala canyon included). Due to this important Pliocene/Pleistocene fluvial erosion combined with isostatic rebound of the plateau, the structural uplift has probably amplified the total tectonic uplift.

The faults and flexures have a major influence on the groundwater movement and runoff water concentrates along tectonic discontinuities. Moreover, rock weathering and erosion is enhanced where adjoining bedrock is mould and brecciated. For such reasons many channels developed their course along tectonic lineaments (Fig. 2). "Fault mirrors" parallel to thalwegs are frequently observed along the valley slopes in the canyon. Consequently sudden changes in directions (Fig. 3c) of thalweg segments are often controlled by faults and structural joints. On the other hand, some fixed meanders of the deeply incised tributaries show a pattern that completely neglects the presence of faults (Fig. 3a). The meander pattern is then either antecedent to the local tectonic features or inherited to the structure and lithological characteristics of overlying strata that are now eroded. This is obvious when comparing such fixed meanders to a similar sinuous meander pattern along thalwegs of undeep valleys incised into soil or regolith, or into the soft MaestrichtianLower Paleocene "Muwaqqar Chalk-Marl" Formation on the plateau (Fig. 3b). The opposite has been observed too: linear segments of fixed valleys in deeper parts of the canyon sometimes do not show evidence of faults or joints at the present thalweg. Such meanders and thalweg patterns may be superimposed on the present regime.

The deep incision of the Lower Mujib canyon happened some kilometers $\mathrm{N}$ of the SSF while most large rivers (e.g. Wadi Zerqa Ma'in to the $\mathrm{N}$ and Wadi Hasa to the $\mathrm{S}$ ) on the eastern rift shoulder developed along important fault lines. This exception is assigned to the resistant basalt sheets that 


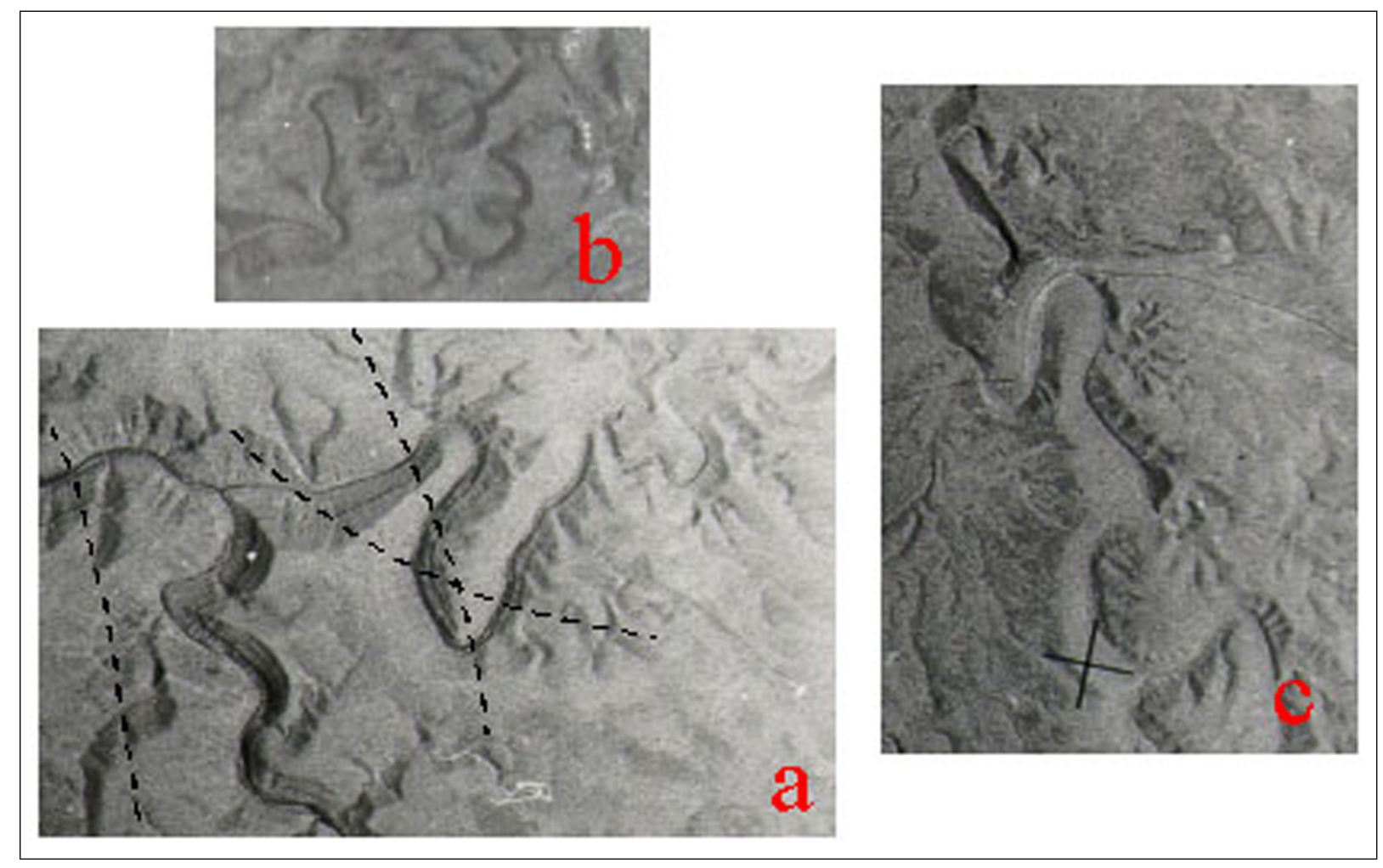

Fig. 3. Aerial photographs; (a) antecedent meander pattern of a deep incised valley neglecting present faults (dashed lines); (b) typical sinuosity of undeep wadis incised in soil, regolith or soft sediments; (c) tectonic-controlled bayonet-pattern of the Upper Nukheila canyon.

cover the Shihan plateau with a maximal thickness of circa $90 \mathrm{~m}$ close to the source area at Jebel Shihan.

Another tectonic factor may have played a role in the position of the Mujib canyon: according to Khalil (1992) an E-W broad asymmetrical anticline folded the strata between the Wadi el-Mujib and Wadi ash Shaqiq and plunges towards the E. This could be part of a antecedent wider monoclinal structure bounded to the $\mathrm{S}$ by the SSF and to the $\mathrm{N}$ by the Dhiban E-W synclinal axis; at the rift margin the supposed monoclinal structure reached its highest elevation (steep cliffs of Cambrian sandstone at the Mujib fandelta) but it died out quickly to the east. The Mujib may have incised in an obsequent way through the structurally weaker rocks near the axial track of this monoclinal structure, so that at present no topographic expression but an inverted relief is left after the deep fluvial incision. In a certain way, this type of evolution can be compared to the five impressive erosional craters on the western side of the DST, called the "makhteshim Ramon, Qatan, Gadol", and the twin "makhteshim of Har Arif" ("makhteshim": plural of "makhtesh", Hebrew for mortar, used internationally for similar land forms, as a term that is more specific than "erosion cirque" or "breached anticline"). These are elliptical valleys surrounded by steep walls composed of hard rocks at the top and friable rocks at the bottom, and drained by one major stream (Mazor, 1993). In these cases, however, the monoclinal structures are charac- terized by steeper dips and the axes show no specific directional plunging, compared to the case of the Mujib. The deep canyon of Wadi Nukheila runs roughly NNW-SSE crossing the El-Lajjune Syncline but seems to have developed principally along a northern offshoot of the Lower Miocene NWSE KFF system: the Wadi Nukheila is bounded on both canyon flanks with numerous dip-slip graben-faults. At the northern side of the canyon complex Wadi Qatar developed inside a N-S directed graben structure. Its incision is however less important as well in plan-view as in elevation-view, except at its lower part where the incision suddenly accelerates and the channel ends in a hanging valley at its confluence with Wadi el-Su'eida.

The incision of the Mujib canyon is estimated to be younger than the plateau basalt eruptions as the basalt, exposed on the plateau edge, did not flow into the canyon. Previous K-Ar datings on the Shihan plateau basalts by Barbieri $^{1}$ et al. (1980), Duffield ${ }^{2}$ et al. (1988) and Steinitz and Bartov $^{3}$ (1992) indicate a Late Miocene/Early Pliocene age $\left(6.0 \pm 0.5 \mathrm{Ma}^{1}, 6.0 \pm 1.2 \mathrm{Ma}^{1}, 6.1 \pm 0.2 \mathrm{Ma}^{2}\right)$ for the Shihan plateau basalts and an age of $8.8 \pm 0.2 \mathrm{Ma}^{3}$ for the basalt near Shukeik on the Dhiban plateau. Steinitz and Bartov (1992) calculated for first-order valleys on the eastern shoulder an average incision rate of $0.23 \mathrm{~mm} / \mathrm{yr}$ for the age interval $6.0-2.6 \mathrm{Ma}$ and of $0.33 \mathrm{~mm} / \mathrm{yr}$ for the last $0.6 \mathrm{Ma}$. These rates, derived from their study on Wadi Zerqa Ma'in, suggest 

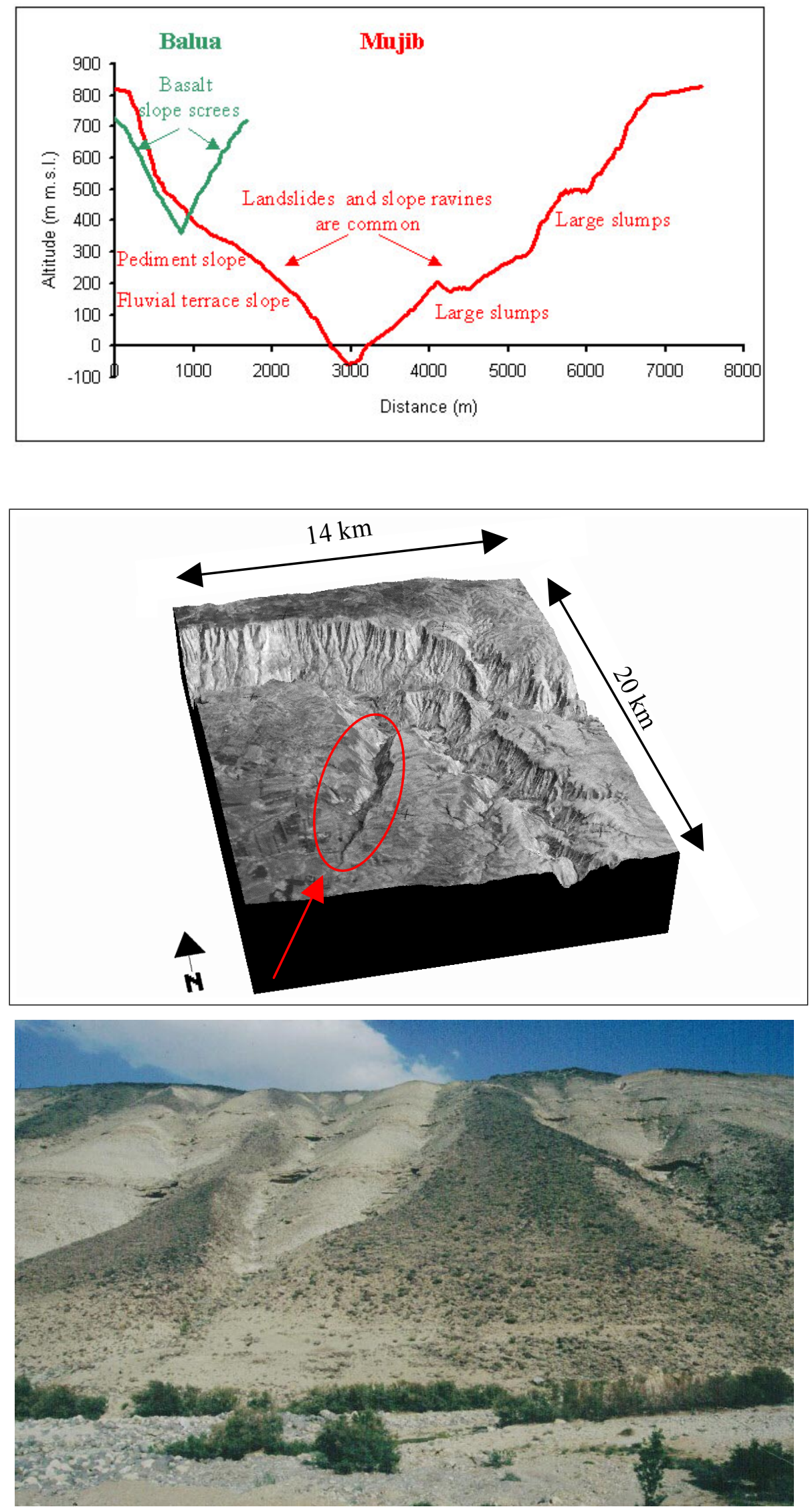

Fig. 4. Typical transversal profile of Wadi Balua (green) and Wadi el-Mujib (red). The V-shaped valley slopes of Wadi Balua are protected by basalt screes while dynamic slopes form complex, often asymmetric profiles in Wadi el-Mujib.
Fig. 5. Top: linear incision of Wadi Balua (red arrow). Bottom: basalt screes cover most of the Balua slopes; inverted relief appears along slopes where thick basalt screes filled ancient slope ravines. 


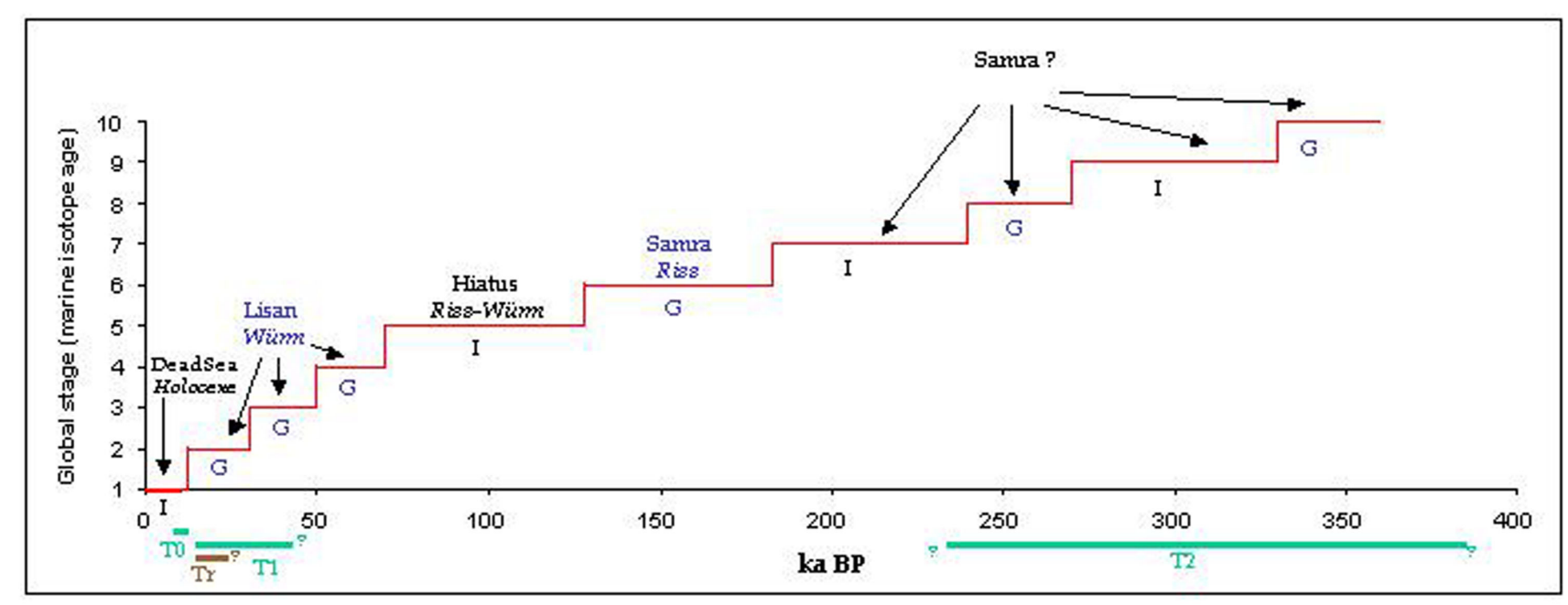

Fig. 6. Global versus regional climate stages during the Late Quaternary: the Dead Sea period, the Lisan period and the Samra period (based on Neev and Emery, 1995). The fluvial terrace accumulations T2, T1, and T0, and the travertine Tr, found in the Mujib canyon, are indicated below the $\mathrm{X}$-axis. $\mathrm{I}=$ interglacial, $\mathrm{G}=$ glacial.

that at 3.4-4 Ma the incision of wide valleys at the eastern Dead Sea fault scarp had already reached sea level elevation. They based their calculations on the age and settings of the basalt rocks exposed in the Wadi Zerqa Ma'in canyon area. In a field campaign conducted in October 2001, samples of different basalt outcrops in the Mujib area (the Shihan plateau basalts, the Wala or Hidan basalt) were taken and submitted for dating. Location, altitude and setting of each basalt sample, together with the dating results will allow a reconstruction of the erosion rates in the Mujib and Wala area and to compare them with the results of Steinitz and Bartov (1992).

At about $25 \mathrm{~km}$ E of the Dead Sea it captured several major tributaries draining a large part of the Mujib Basin extended far to the S and the SE. One of these tributaries, the Wadi Balua, has cut trough the resistant basalt exploiting a large SSW-NNE fault. Here the slopes are almost completely covered by basaltic screes protecting them from rapid degradation. As a result the valley of the Wadi Balua is generally $\mathrm{V}$-shaped and the slope morphology is much less complex than elsewhere in the canyon complex (Fig. 4).

The screes were formed by rockslides starting at the plateau edge (Fig. 5). They were triggered by fast weathering and erosion of the basalt layers (horizontally and vertically jointed) in periods of colder and wetter climatic conditions during the Pleistocene Glacials (Fig. 6). According to the study of Horowitz (1968) in the Upper-Jordan Valley the Riss-Würm Hiatus was warm and dry, the period of 60-11.5 ka BP was characterized by a humid climate, with alternating cool (Early Würm, Main Würm, Late Glacial) and warm (52-32 ka BP, 22-16 ka BP) phases (Upper-Jordan Valley), while the Post Glacial has been warm and dry, but warm and humid during the Atlantic phase (7.5-5 ka BP). Neev and Emery (1995) stated that high lake levels (-200 m m.s.l.) occurred during the period 9-7.8 ka BP. According to
Bar-Matthews et al. (2000) research results on speleothems in the Soreq cave (Central Israel) indicate that $124-119 \mathrm{ka}$ BP, 108-100 ka BP, 85-79 and 8.5-7 ka BP were periods of high hydrological activity.

Black varnish (patina) covers the sun-exposed surface of the basalt blocks and developed under warm and dry conditions once the basalt blocks were fixed in a "dead" scree. The carbon fixed in the patina during formation has been dated by AMS ${ }^{14} \mathrm{C}$ as a terminus ante quem for the scree development (De Jaeger et al., 2001). The age of $14760 \pm 500$ years BP (dating CAMS-70486) assumes that the scree developed in the Last Glacial Maximum (LGM), probably coeval with the deposition of stratified screes of angular limestone and chert fragments that are found elsewhere in the canyon but at similar altitudes and slope degrees $\left(30-35^{\circ}\right)$.

Three fluvial terrace levels have been well preserved in the central Mujib canyon: the oldest (T2) is the thickest accumulation ( $>50 \mathrm{~m}$ ) while the younger one (T1), immediately above the present floodplain, has a main thickness between $5-10 \mathrm{~m} . \mathrm{T} 0(<5 \mathrm{~m})$ is the third and youngest terrace level, observed in the present floodplain. Another, older terrace level T3 is only locally preserved on structural flats along the slopes and consists of a cemented breccia/conglomerate. Because no sandstone but limestone is exposed in the source area, Optical Stimulated Luminescence (OSL) dating of the terrace material is difficult. However, sufficient quartz has been found in two samples taken from the lower part of T1 and $\mathrm{T} 0$ and have been dated at $42.9 \pm 2.6 \mathrm{ka} \mathrm{BP}$ (dating X403) respectively $9.6 \pm 1.0 \mathrm{kaBP}$ (dating X404) (De Jaeger et al., 2001). By Uranium-series the carbonate cement of the basis of T2, a terrace conglomerate, has been dated, indicating an age of $383660 \pm 29760$ years BP. In the middle part of the T2-accumulation the same dating method applied on a synsedimentary calcrete layer gave an age of $229620 \pm 1880$ years $\mathrm{BP}$, indicating that the $\mathrm{T} 2$-terrace must correspond to a 


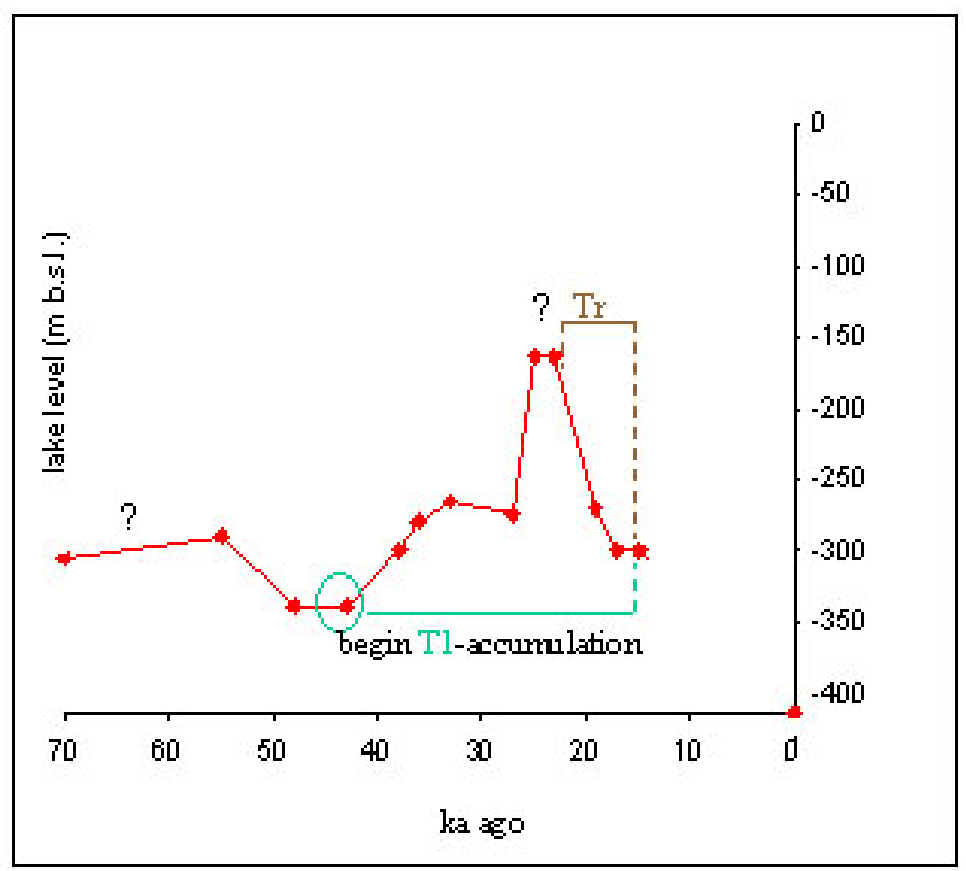

Fig. 7. Lake level fluctuations during the last 70000 years (based on Bartov et al. (2000), Machlus et al. (2000) and Stein et al. (2001). The sudden lake level rise after the low stand of $330 \mathrm{~m}$ between $48-43 \mathrm{ka}$ BP has triggered the accumulation of the T1-terrace in the Mujib canyon. Important travertine deposition occurred up to $22-16 \mathrm{ka} \mathrm{BP}$, as long as the "B2/A7" aquifer was filled at maximum by percolated water after a long period of higher precipitation and/or lower evaporation.

Mid-Pleistocene valley aggradation. Headward incision between the deposition of T2 and T1 started from the base level at the Dead Sea and has reached to a $3 \mathrm{~km}$ upstream of the Nukheila-Mujib confluence where T1 merges with remnants of $\mathrm{T} 2$.

It remains difficult to understand the trigger mechanisms for the fluvial terrace accumulations in the canyon development. Both terraces however, are assumed to be fluvial accumulations in periods of higher precipitation during the Pleistocene, when more sediment could be transported by the rivers and when the lake levels in the rift basins were higher that implies a higher base level. T1 was accumulated in the LGM, perhaps genetically related to the changing levels of Lake Lisan as discussed in Bartov et al. (2000), Machlus et al. (2000) and Stein et al. (2001)(Fig. 7). By correlating fandelta and lacustrine deposits they established a Lisan lakelevel curve for the period between 55 and $35 \mathrm{ka} \mathrm{BP}$, corresponding to the isotopic stage 3 of the global record. The curve shows that low lake levels characterized this period with a minimum $(\sim-330 \mathrm{~m}$ m.s.l.) between 47 and $43 \mathrm{ka}$ $\mathrm{BP}$, indicating dry climatic conditions. The sudden important rise of the lake level following this minimum triggered the T1-accumulation that continued through the Late Glacial, characterized by wet conditions. The T0-accumulation occurred in the Early Holocene during a last cold phase, described by Neev and Emery (1995): the period 11-9.4 ka BP was characterized by high lake levels in the rift basin. Large travertine terraces have been deposited along the canyon slopes near the base of the "B2/A7" aquifer. The "B2/A7" is the main "Amman-Wadi Sir" aquifer system in the area, composed of Campanian silicified limestone at the top, Santonian chalk-marls and Turonian marly limestone intercalated by chert layers at its lower part. The base of the aquifer rests on the impermeable rocks, mainly mudstone, of the Cenomanian Shu'ayb Formation. Four samples of the travertine are recently dated (De Jaeger et al., 2001): two samples taken near the top are dated by AMS ${ }^{14} \mathrm{C}$ at $17130 \pm 70$ years BP (dating NZA-13225) respectively $16295 \pm 65$ years BP (dating NZA-13226), a third taken near the base, is dated by Uranium-series at $22850 \pm 535$ years BP. These ages correspond with the end of the LGM, or the final shrinkage of Lake Lisan (Machlus et al., 2000) after a long period of important humid conditions and aquifer fill-up. Another travertine deposit near the hanging valley of Wadi Balua is not related to the B2/A7 aquifer but to a waterfall. Its age is dated by Uranium-series at a Late Glacial age of $31325 \pm 710$ years BP. The travertine deposition was reduced to a much slower rate and even ended at most places with the transition to the dry climatic conditions of the Holocene. The abovementioned results indicate that the Late Quaternary deposits in the canyon coincide with regional climatic changes. This is confirmed during the October 2001 field campaign by the observation of an equal sequence of similar terrace deposits T3, T2, T1 and T0 in the Wadi el-Hasa canyon, situated at about $100 \mathrm{~km} \mathrm{~S}$ of the Wadi el-Mujib canyon. Although tectonic influence in Late Quaternary deposits is not excluded: local (peri-) lacustrine sediments aggraded upper parts of the Wadi el-Su'eida portion of the Mujib canyon complex and of 


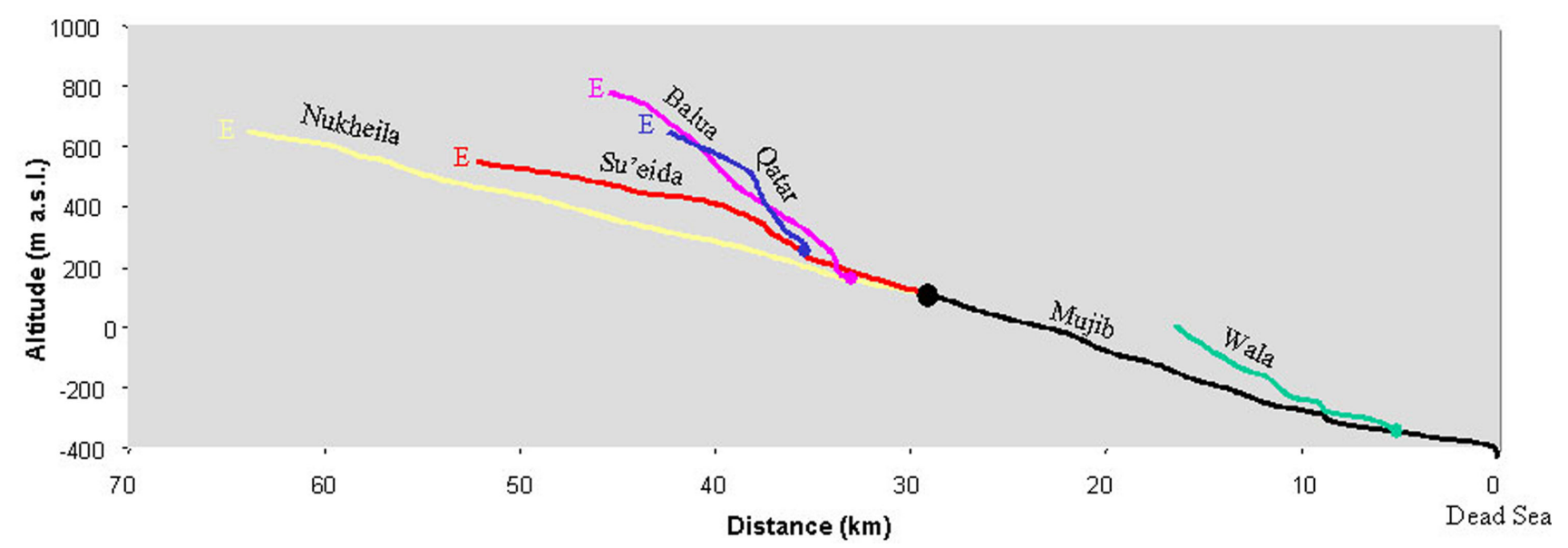

Fig. 8. Longitudinal profiles of the main wadis in the Mujib canyon complex, from the escarpment (E) downstream to the mouth at the Dead Sea (415 m m.s.l.); dots mark confluences. Shorter tributaries show higher delay in headward erosion. along the tributaries Qatar, Balua and Su'eida. The longitudinal profile of Wadi Wala is calculated only for the section below sea level.

the Wadi el-Hasa canyon during the wet Lisan period, but were both triggered by locally tectonically triggered river blockages (flexures). Moreover, the travertine terraces appear at the base of the "B2/A7" aquifer, but their position is as well related to the presence of tectonic discontinuities along which groundwater seeps faster.

\subsection{The Holocene}

The level of the Holocene Dead Sea drops at a high rate. This is not only due to continued tectonic subsidence of the Dead Sea basin but as well important is the desiccation of the regional climate since the Holocene and the use of fresh water by Man (e.g. the Jordan River) causing a serious reduction of water input into the Dead Sea (Enzel et al., 2001). At present day erosion is the dominating fluvial process along the Holocene channels in the canyon. T0 has been incised and renewed bedrock incision can be observed. The potential energy for fluvial erosion is high since the wadis have not reached a state of equilibrium along their longitudinal profile (Fig. 8). Wadi Qatar and Wadi Balua show a steep gradient and a convex profile due to the delay of headward erosion with respect to their erosion base or the principal wadis Nukheila and Mujib. Intense normal faulting caused the hanging valley at the mouth of Wadi Balua. Waterfalls and travertine deposits can be observed here. As can be noticed on the profile, headward erosion goes faster along Lower Wadi el-Su'eida before its confluence with the Mujib.

Wadi Nukheila and Wadi el-Mujib form the main channels and have a straight to slightly concave profile. Wadi Wala has a slightly concave profile with a steep gradient. Higher precipitation amounts in the $\mathrm{N}$ and NE of the Mujib basin enhances fast headward erosion along the lower reaches of Wadi Wala. The secondary knickpoints along the profiles can be assigned to differences in rock resistance, e.g. where soft marl alternates with a resistant chert layer.
The Holocene fluvial incision is stimulated by the drying of the climate characterized by a high variability of the yearly precipitation amounts (mean: $<=100 \mathrm{~mm} /$ year for the canyon and the E-SE of the Mujib basin, while $<350 \mathrm{~mm} /$ year over the plateau areas) and of the rainfall distribution that is concentrated in a few events. During such events surface runoff causes sheet- and gully erosion over the affected areas in the Mujib basin. This results in mud streams through the canyon with a high competence. Earthquakes along the rift often destabilize the slopes in the canyon (De Jaeger et al., 1999; De Jaeger, 2000). Faults may be reactivated and structural joints may open rock masses causing mass movements. Seismic activity may disturb the weathered shale and gypsum of the "Fuhays-Hummar-Shu'ayb" Formation. Inside these susceptible layers slide planes (rotational and translational) are easily formed resulting in landslides that may include large masses of the overlying Turonian "Wadi as Sir Limestone". If the slided mass enters the wadi bed, a new thalweg will develop around the obstacle. At some places remnants of Holocene lake sediments were observed along the valley slopes where once a landslide dam was formed.

\section{The mouth of the Wadi el-Mujib canyon}

No subaerial delta sediments are left at the old gorge of the Wadi el-Mujib despite the drop of the lake level. This is due to important Upper Pleistocene and Holocene downfaulting along the eastern rift fault. Khalil (1992) suggests several $100 \mathrm{~m}$ post-Lisan downfaulting and states that a zone of breccia is located just $S$ of the present Wadi el-Mujib fandelta, associated with well-rounded coarse-grained conglomerates that are probably remnants of a post-Miocene fan delta. Starting at about $1.5 \mathrm{~km}$ upstream its present mouth, the $\mathrm{Mu}-$ jib river flows through the Cambrian Umm Ishrin Sandstone by exploiting a $073^{\circ} \mathrm{N}$ trending fissure, some $1300 \mathrm{~m}$ to the 


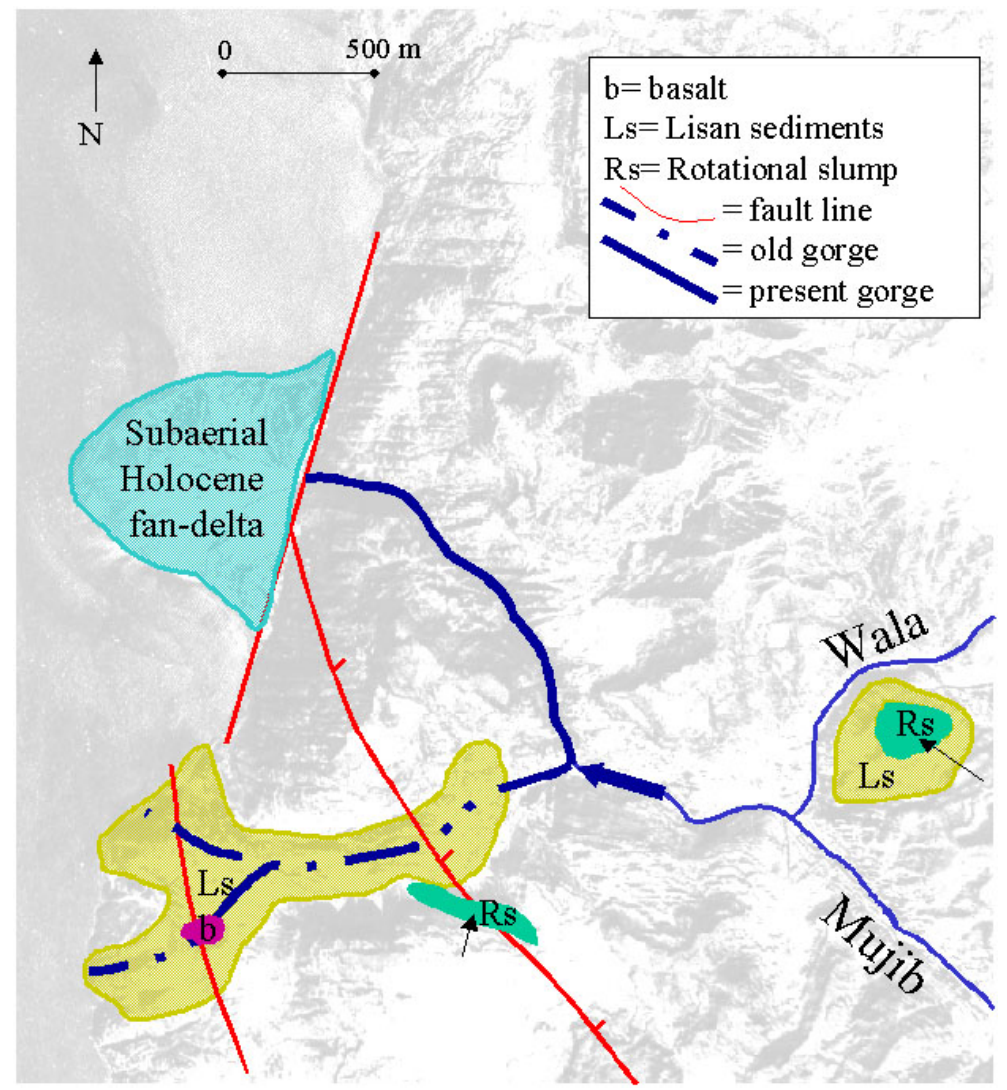

Fig. 9. Tectonic and geomorphologic situation of the Pre-LGM Mujib gorge and the Holocene Mujib fandelta (background: Corona image, 1967).

$\mathrm{N}$ with respect to its previous gorge (Fig. 9). Sediments sampled at the lower exposed part of the present fandelta accumulation have recently been dated by OSL at a Holocene age of $10 \pm 1 \mathrm{ka}$ BP (dating X406) (De Jaeger et al., 2001). It is suggested that the shift from the old Mujib mouth to the present gorge is genetically related to 1) rapid incision and river deviation following the large lake level drop by the end of the Lisan period and/or 2) the trigger of a fault movement inside the mouth area. The present gorge is connected to the Mujib $1.5 \mathrm{~km}$ upstream at a Pleistocene cut bank or the concave side of a Pleistocene meander, now being aggraded by flood debris (silt, wood). There, the width of the Pleistocene Mujib gorge is $26 \mathrm{~m}$ (widening to $>100 \mathrm{~m}$ at the Dead Sea) while the young age of the present gorge is proved by its width of only $5 \mathrm{~m}$ (widening to $26 \mathrm{~m}$ at the fandelta or the Dead Sea).

Finally, the fluviolacustrine sediments that fill the previous Mujib gorge have been dated by OSL near the base at an age of $73 \pm 7 \mathrm{ka}$ BP (dating X405) (De Jaeger et al., 2001). This means that these sediments were deposited at the end of the Samra-Lisan Hiatus that is supposed to be equivalent to the Riss-Würm Interglacial (Neev and Emery, 1995). During this dry climatic phase the Samra Lake dropped to a minimum level of $400 \mathrm{~m}$ below mean sea level; that is somewhat below the altitude of the site were the sample is taken.

\section{Conclusions}

The deep incision of the Mujib canyon complex must be assigned to the intense tectonic subsidence of the Dead Sea basin. However, recent results obtained by absolute dating of Late Quaternary deposits indicate that climatic changes played a major role in the geomorphologic evolution of the canyon complex and its mouth at the Dead Sea. While the inherited tectonic structures in the area are the base for the drainage pattern in plan-view, it is the combined effect of tectonic activity and changing climatic conditions that adjusted the slope- and river profiles in elevation-view, as well as the mouth of the Mujib.

1. Plan-view: the fault net in the area is genetically related to the SNSZ, the KFF system and most of all to the DST. Wadi channels in the canyon complex principally developed consequently to tectonic discontinuities such as fault lines and monoclinal, anticlinal and synclinal axes. The main Mujib canyon has incised around the resistant basalt sheets on the Shihan plateau, probably along the axis of a less developed monocline that had its highest elevation in the $\mathrm{W}$ at the rift border. The continuous linearity of Wadi Balua is due to the presence of a prominent synclinal axis, while broad but fixed meanders occur along the course of Wadi Nukheila and upper Wadi el-Su'eida notwithstanding the fact that they 
both appear to be developed along tectonic structures (discontinuous KFF graben-faults respectively the SSF system). Their valley is more mature and a part of the meanders seem inherited from a former bedrock configuration superimposed on the actual bedrock exposure or are antecedent to the present regime. On the other hand many meanders in the deeper parts of the canyon present a "bayonet" geometry that is clearly related to the present tectonic setting.

2. Elevation-view:due to normal rift faulting since the Pliocene there is a height difference of about 1000$1500 \mathrm{~m}$ between the plateau and the Mujib base level or the Dead Sea level, ensuing high relief energy. Starting at about $50 \mathrm{~km} \mathrm{E}$ of the rift the main wadis of the Mujib basin incised a deep canyon complex. The longitudinal profiles testify to a non-equilibrium state and the potential erosion remains high. Absolute datings (OSL, U-series, AMS ${ }^{14} \mathrm{C}$ ) of deposits, such as fluvial terraces, lacustrine and fluvial fandelta sediments, travertine terraces and desert varnish, indicate important Late Quaternary climate changes in this part of Central Jordan. Tectonic control played a minor role and is especially expressed where local tectonic structures (faults, flexures) determined the location of travertine terraces, of rapids and hanging valleys, of large slumps, and of local valley aggradation. Earthquakes along the rift caused many landslides along the canyon slopes. This elevation-view development is confirmed by the observations done in the Wadi el-Hasa canyon, which drains into the southern Dead Sea basin.

3. The mouth of the Mujib: the deviation of the Lower Mujib course from its Pleistocene mouth to its present small gorge at about $1300 \mathrm{~m}$ to the $\mathrm{N}$, occurred at the end of the Pleistocene, following the high levels of Lake Lisan between 27-23 ka BP. Left remnants prove that the Late Pleistocene fandelta was much higher, probably reaching the top of the sandstone cliffs of the fault escarpment, and much wider than the Holocene fandelta. The rapid drop of Lake Lisan's highest level from about $165 \mathrm{~m}$ m.s.l. to the Holocene Dead Sea level of about $400 \mathrm{~m}$ m.s.l. caused strong fluvial incision along the $073^{\circ} \mathrm{N}$ trending wide fissures. In this way the Mujib was captured at about $1.5 \mathrm{~km}$ upstream of the fault escarpment. It remains unproved whether or not postLisan normal faulting in the Mujib mouth area, suggested by Khalil (1992), played an additional role in the deviation of the Mujib to the N.

Acknowledgements. Many thanks to Dr. A. Watchman (James Cook University, Townsville, Queensland, Australia) and to Dr. E. Rhodes (University of Oxford, UK) for sampling and dating of the Late Quaternary deposits described in the paper. The authors extend their sincere thanks to the following persons and authorities for supplementing information used in this study and for the "feedback" in many interesting discussions: Prof. Dr. P. De Paepe, Prof. Dr. P. Jacobs, Prof. Dr. J.-P. Henriet (Ghent University, Gent, Belgium); Prof. Dr. A. M. Abed and Prof. Dr. O. Rimawi (University of Jordan, Amman, Jordan); Geologist I. Alnjjar (Lahmeyer International); Eng. D. Jaser and Dr. A. Batayneh, Eng. M. Fandi, Geologist A. El-Masri, Geophysicist A. R. A. Abueladas (Natural Resources Authority, Amman, Jordan); Dr. U. Eldeen (Gaza University, Palestinian Territories). Thanks to Dr. M. Stein, Dr. Y. Enzel, Dr. J. Avni and M.Sc. Y. Bartov (Hebrew University, Jerusalem, Israel); Prof. Dr. Z. Ben-Avraham (Tel Aviv University, Israel); Prof. Dr. Y. Mart (University of Haifa, Israel). This study is funded by the Fund for Scientific Research Flanders, Brussels, Belgium.

\section{References}

Abed, A. M.: Emergence of Wadi el-Mujib (Central Jordan) during Lower Cenomanian time and its regional tectonic implications, in: Dixon, J. E. and Robertson, A. H. F. (Eds.): The Geological Evolution of the Eastern Mediterranean, Special Publication of the Geological Society, Blackwell Scientific Publications, Oxford, 17, 848p, 1985.

Abed, A. M. and El-Hiyari, M.: Depositional environments and paleogeography of the Cretaceous gypsum horizon in westerncentral Jordan, Sedimentary Geology, 47, 109-123, 1986.

Atallah, M.: Geology and structures of the area east of the Dead Sea, M.Sci.Thesis, University of Jordan (unpubl.), 54p, 1981.

Atallah, M.: Application of remote sensing and field techniques to structural problems of the Dead Sea Rift in Jordan, Ph.D. Thesis, Technical Univ. of Munich (unpubl.), 19-131, 1986.

Atallah, M.: Tectonic evolution of northern Wadi Araba, Jordan, Tectonophysics, 204, 17-26, 1992a.

Atallah, M.: On the structural pattern of the Dead Sea Transform and its related structures in Jordan, in: Al-Yarmouk, A. (Ed.): Pure Science and Engineering Series, Yarmouk University Publications, 1, 127-143, 1992b.

Barberi, F., Capaidi, G., Gasperini, P., Marinielli, G., Santacroce, R., Scadone, R., Treul, M., and Varet, J.: Recent basaltic volcanism of Jordan and its implication on the geodynamic history of the Dead Sea shear zone, Proc. Intern. Symp. Geodyn. Evolution Afro-Arabian Rift System, Rome, 667-683, 1980.

Barjous, M. and Mikbel, S.: Tectonic evolution of the Gulf of Aqaba - Dead Sea transform fault system, Tectonophysics, 180, 49-59, 1990.

Bartov, Y., Agnon, A., Enzel, Y., Reches, Z., and Stein, M.: Reconstruction of Lake Lisan levels by sequence stratigraphy of shore and lacustrine sediments at Massada. Program and Abstracts. Ben Avraham, Z. (Ed.): The Frist Stephan Mueller Conference of the European Geophysical Society (EGS). From Continental Breakup to Collision. Grand Nirvana Hotel, Dead Sea, Israel, June 11-16, 2000, Tel Aviv University, p 50, 2000.

Bar-Matthews, M., Ayalon, A., and Kaufman, A.: Timing and hydrological conditions of Sapropel events in the Eastern Mediterranean, as evident from speleothems, Soreq cave, Israel, Chemical Geology, 169, 145-156, 2000.

Ben-Avraham, Z. and Ten Brink, U.: Transverse faults and segmentation of basins within the Dead Sea Rift, Journal of African Earth Sciences, 8(2-4), 603-616, 1989.

Bender, F.: Geology of the Arabian Peninsula: Jordan. Geological Survey Professional Paper, US Government Printing Office, Washington, 560-1, 36p, 1975.

Bentor, Y. K. and Vroman, A.: The Geological Map of Israel on 1:100 000 scale, Ser. 1, Sheet 16, Mt. Sedom Geol. Surv. of Israel, 1960. 
Buchbinder, B. and Zilberman, E.: Sequence stratigraphy of Miocene-Pliocene carbonate-siliciclastic shelf deposits in the eastern Mediterranean margin (Israel): effects of eustasy and tectonics, Sedimentary Geology, 112, 7-32, 1997.

De Jaeger, Ch., De Dapper, M., De Vliegher, B. M., Goossens, R., Risack, S., Closson, D., Cornet, Y., and Ozer, A.: The use of very high resolution and stereoscopic satellite imagery (Russian TK-350) for the geomorphological mapping of the Wadi Mujib canyon in Jordan. Post Conference Proceedings Volume: Trends in Geoinformatics, Technology and Applications, International Conference on Geoinformatics for Natural Resource Assessment, Monitoring and Management, March 9-11, 1999, IIRS and ITC, Dehradun, India, 481-489, 1999.

De Jaeger, Ch.: Influence on landsliding and slope development of the particular environment of the Dead Sea region. A case study for the Wadi Mujib canyon (Jordan), in: Bromhead, E., Dixon, N., and Iibsen, M.-L. (Eds.): Landslides in Research, Theory and Practice, Thomas Telford, London, 1, 421-426, 2000.

De Jaeger, C., De Dapper, M., Alnjjar, I., Rhodes, E., and Watchman, A.: Geomorphologic Evidence for Pleistocene Climate Changes in the Wadi Mujib Canyon, Jordan. Past Climate Variability Through Europe and Africa, Abstracts, PAGES, International Conference, 27-31 August 2001, Aix-en-Provence, France, 75 (+ poster), 2001.

Duffield, W. A., McKee, E. H., El Salem, F., and Feimeh, M.: KAr ages, chemical composition and geothermal significance of Cenozoic basalt near the Jordan Rift, Geothermics, 17, 635-644, 1988.

Enzel, Y., Kadan, G., and Eyal, Y.: Holocene Earthquakes Inferred from a Fan-Delta Sequence in the Dead Sea Graben, Quaternary Research, 53, 34-48, 2000.

Enzel, Y., Ken-Tor, R., Gvirtzman, H., Stein, M., and Sharon, D.: Rainfall distribution during Dead Sea lake-level rises and falls: implications for Holocene climates and water resources during long-term droughts in the Middle East. Past Climate Variability Through Europe and Africa. Abstracts, PAGES, International Conference, 27-31 August 2001, Aix-en-Provence, France, 7879 (+ poster), 2001.

Freund, R., Garfunkel, Z., Zak, I., Goldberg, M., Weissbrod, T., and Derin, B.: The shear along the Dead Sea Rift, Philos. Trans. R. Soc. London, London, Great Britain, A267, 107-130, 1970.

Freund, R., Zak, I., and Garfunkel, Z.: Age and Rate of the Sinistral Movement along the Dead Sea Rift, Nature, 220, 253-254, 1968.

Garfunkel, Z:: Tectonics of the Western Margins of the Southern Arava, PhD. Dissertation, Hebrew University of Jerusalem, 204pp, 1970.

Ginat, H., Enzel, Y., and Avni, Y.: Translocated Plio-Pleistocene drainage systems along the Arava fault of the Dead Sea transform, Tectonophysics, 284, 151-160, 1998.

Horowitz, A.: The Plinology of Young Sediments in the Upper Jordan Valley (From the Hebrew), The Institute of Oil and Geophysics Research Report, No 1031, Jerusalem, in: LaBianca, $\emptyset$. S. and Lacelle, L. (Eds.): Hesban 2: Environmental Foundations, Andrews University Press, Berrien Springs, USA, 147p, 1968.

Horowitz, A.: Palynological evidence for the age and rate of sedi- mentation along the Dead Sea Rift, and structural implications, Tectonophysics, 141, 107-115, 1987.

Kashai, E. L. and Croker, P. F.: Structural geometry and evolution of the Dead Sea - Jordan rift system as deduced from new subsurface data, Tectonophysics, 41, 33-60, 1987.

Khalil, B.: The geology of the Ar Rabba area - Map sheet NO. 3152 IV. Geology Directorate NRA, Geological Mapping Division, Amman, 22, 106p, 1992.

Machlus, M., Enzel, Y., Goldstein, S. L., Marco, S., and Stein, M.: Reconstructing low levels of Lake Lisan by correlating fan-delta and lacustrine deposits, Quaternary International, 73/74, 137144, 2000.

Marco, S., Stein, M., and Agnon, A.: Long-term earthquake clustering: A 50000 -year paleoseismic record in the Dead Sea Graben, Journal of Geophysical Research, 101 (3), 6179-6191, 1996.

Mazor, E.: Introduction to the Ramon National Geological Park, Israel Journal of Earth Sciences, 42, 103-114, 1993.

Neev, D. and Emery, K. O.: The Destruction of Sodom, Gomorrah, and Jericho: Geological, Climatological, and Archaeological Background, Oxford University Press, Inc., New York, 155p, 1995.

Powell, J. H. and Khalil, B. M.: Structure and sedimentation of Permo-Triassic and Triassic rocks exposed in small-scale horsts and grabens of pre-Cretaceous age: Dead Sea margin, Jordan, Journal of African Earth Sciences, 17 (2), 131-143, 1993.

Quenell, A. M.: The structural and geomorphic evolution of the Dead Sea Rift, Q. J. Geol. Soc. London, 14, 1-24, 1958.

Quenell, A. M.: Tectonics of the Dead Sea rift, Proc. 20th Int. Geol. Congr., Mexico, 1956, Asoc. Serv. Geol. Afr, 385-405, 1959.

Rabinowitz, N. and Mart, Y.: Seismic tomography of the Dead Sea region: thinned crust, anomalous velocities and possible magmatic diapirism, in: Vendeville, B. C., Mart, Y., and Vigneresse, J. L. (Eds.): From the Artic to the Mediterranean: Salt, Shale and Igneous Diapirs in and around Europe, Geologic Society of London, Special Publication, 174, 79-92, 2000.

Stein, M., Agnon, A., Enzel, Y., Goldstein, S. L., Ken-Tor, R., Migowski, C., and Negendank, J.: Contrasting Climatic Signals in Lake Lisan - Dead Sea Sediments During the last Glacial and the Younger Dryas. Past Climate Variability Through Europe and Africa, Abstracts, PAGES, International Conference, 27-31 August 2001, Aix-en-Provence, France, 149 (+ poster), 2001.

Steinitz, G. and Bartov, Y.: The Miocene-Pleistocene history of the Dead Sea segment of the Rift in light of K-Ar ages of basalts, Isr. J. Earth Sci., 40, 199-208, 1992.

Ten Brink, U. S., Ben-Avraham, Z., Bell, R. E., Hassouneh, M., Coleman, D. F., Anreasen, G., Tibor, G., and Coakley, B.: Structure of the Dead Sea pull-apart basin from gravity analyses, J. Geophys. Res., 98, 21 877-21 894, 1993.

Wdowinski, S. and Zilberman, E.: Systematic analyses of the largescale topography and structure across the Dead Sea Rift, Tectonics, 16(3), 409-424, 1997.

Zak, I. and Freund, R.: Asymmetry and basin migration in the Dead Sea Rift, Tectonophysics, 80, 27-38, 1981.

Zilberman, E.: The Mahmal Graben and Nahal Hawwa: An introduction to the paleogeography of the central Negev in the Miocene, Isr. J. Earth Sci., 42, 197-209, 1993. 